\title{
Zuzana Uhde
}

ORCID: 0000-0002-9885-4260

Czech Academy of Sciences Institute of Sociology 1

Hana Maříková

ORCID: 0000-0002-0728-9981

Czech Academy of Sciences

Institute of Sociology 2

\section{Obstacles to caring institutions in eldercare: The Czech Republic as a social laboratory of capitalist transformation ${ }^{3}$}

\begin{abstract}
Summary
The issue of eldercare is becoming more and more important in late modern societies due to the aging of the population and the growing need for care. The article deals with formal care for older people (in residential facilities and home care) with a focus on the Czech Republic as one of the former real-socialist countries. Here, a significant transformation

1 Correspondence: Zuzana Uhde, Gender \& Sociology Department, Institute of Sociology of the CAS, Jilská 1, 11000 Praha 1, Czech Republic; author's email address: zuzana.uhde@soc.cas.cz

2 Correspondence: Hana Mař́ková, Gender \& Sociology Department, Institute of Sociology of the CAS, Jilská 1, 11000 Praha 1, Czech Republic; author's email address: hana.marikova@soc.cas.cz

3 This work was supported by the project Configurations of Elderly Care in the CR: Labour, Love and Money (No. 15-078985, GAČR) and RVO No. 68378025.
\end{abstract}


of the eldercare system began to take shape in the wake of capitalist transformation. However, it also took place in a society with relatively egalitarian societal attitudes and expectations. The article draws from qualitative research based on interviews with care workers in direct care and expert interviews with professionals working at different levels of eldercare system in the Czech Republic. Our analysis is based on the feminist theory of care that allows us to critically reflect on both the changes and the unintended consequences of the public care policies settings, and the perspectives of communication partners on how to provide quality care. Our goal is to identify elements that are perceived positively in connection with the rules setup and which, from the point of view of individual actors in formal care, help to create a genuine environment of caring institutions.

Key words: caring institutions, ethics of care, formal eldercare, Czech Republic, commodification

\section{Introduction}

In the late modern society, eldercare is becoming one of the main public issues. The article focuses on formal eldercare on the example of the Czech Republic. Given the recent history of real socialism, the Czech Republic can be analysed as a social laboratory of the rapid insertion of market relations into the area of care in the wake of the capitalist transformation starting from the 1990s within the context of a society where a relatively egalitarian ethos and societal expectations still prevailed.

Our analysis is based on the feminist theory of care, especially drawing from Joan Tronto's political theory of care. The theory and ethics of care puts at the forefront intersubjective relationships of care, the reflection of which allows us to identify both the negative elements of the social structures within which the real care practices in the late modern society are embedded, and the positive norms which good care is dependent on and which should constitute the foundation of caring institutions. Our analysis is based in particular on qualitative research employing interviews with care workers, representatives of eldercare providers and experts working in the field of policy negotiation with regard to eldercare in the Czech Republic. In the first section, we will outline the theoretical starting points of our analysis with an emphasis on identifying the societal pressures that caring institutions have to manage. In the second section, we will focus on an internationally contextualized interpretation of the changes in eldercare policies in the Czech Republic. After presenting the methodology, we will move onto the analysis of our interviews, which, in view of the theoretical framework, we will focus first on the clash of ideas of good care with the institutional conditions defined both by the economic framework and the public policy. Next, we will analyse the working conditions of care workers with regard to the contesting needs for care on the part of the people to whom formal care is provided, and the needs for care on the part of those who provide it. Finally, we look at the elements that are perceived positively in connection with the rules setup, and which help care workers to create an environment of a caring institution. 


\section{Why do we need caring institutions?}

Joan Tronto (2010) formulates principles that are essential to setting up a caring institution providing quality care: "first, a clear account of power in the care relationship and thus a recognition of the need for a politics of care at every level; second, a way for care to remain particularistic and pluralistic; and third, that care should have clear, defined, acceptable purposes" (Tronto, 2010, p. 162). According to Tronto, this requires perceiving care as a process that entails not only attention to the needs of care-receivers, but also to the needs of care workers, a reflection on the division of responsibilities and a continuous assessment of the whole process of care. At the same time, she points out that neither the market model nor the ideal of family care necessarily provide sufficiently clear starting points for the setting up of a caring institution. Although the practice of family informal care strays away, in a number of respects, from an inherently harmonious ideal (Dudová, Vohlídalová, 2018), the normative notions of home care today to a large extent determine the dominant ideal of good care. The care process in the family setting is based on an intuitive perception of the intimate relationship of family members and their mutual familiarity. To the contrary, Tronto holds that the principles of a caring institution require a conscious political process of negotiation, participation, and critical reflection. In a similar vein, in her proposition of caring bureaucracy, Sophie Bourgault (2017) emphasizes the need to align a clear organisation of relationships (associated with bureaucracy) with the ethics of care. The lack of hierarchy and the absence of rules in care institutions, according to patterns of family care, might not necessarily lead to improvement in care provision and working conditions for care workers. However, organisational rules in care institutions need to be adequately adapted to the purpose of caring institutions.

Joan Tronto's political and moral theory of care is one of the key feminist approaches to care. Her definition of the concept of care is based on five stages with which certain values are associated: firstly, caring about, i.e. the needs of others are recognized and the decisive value here is attentiveness; secondly, taking care of, meaning the assumption of responsibility, which is a key value here; thirdly, care-giving, i.e. physical work is present and competence comes to the fore as a value; and, fourthly, care-receiving as a feedback in which responsiveness plays a role (Tronto, 1994, pp. 106-108). The fifth stage entails caring with and the values of trust and solidarity intertwined with it (Tronto, 2013). In her view, these stages are an integral part of a holistic care practice if it is to be morally justified from the perspective of all involved actors.

Tronto rejects the relationship between a mother and a child as a metaphor for formulating the principles of care. In this point her approach differs from other influential approaches, namely from Sara Ruddick's concept of maternal thinking (Ruddick, 2002) and Virginia Held's ethics of care (Held, 2006). Tronto criticizes a narrow approach in the ethics of care based on the mother-and-child relationship because it confirms the existing power framework and the false ideal of individualism that consolidates the reductive and parochial concept of care and responsibility attached to the nuclear family (Tronto, 1994, p. 171). Moreover, the ethics of care based on the mother-and-child relationship 
restricts care relationships merely to relations permeated by fundamental inequalities by definition (see Tronto, 2008). In general, care relationships may not necessarily be pervaded with inequality. If we look at the care practice in a broader social context, Tronto insists that the idea of equality does not deny the principles of care and, on the contrary, the concept of care does not deny equality.

On the other hand, intersubjective relations never involve relations of independent individuals, but rather a graduated range of mutual interdependence and asymmetric reciprocity ${ }^{4}$. Care as a form of intersubjective relationship is inherently asymmetric, though this does not rule out equality in a social relationship. Equality in a social relationship of asymmetric reciprocity is characterised by alternation, i.e. one has to take into account a longer period of time over which relations of interdependence are enacted (Young, 2007). Despite the relationship between a particular care worker and a particular older person in the institutional eldercare being asymmetric, what is primary from the point of view of social relations is that everybody needs to be taken care of to some degree in the course of one's life and that every individual has caring responsibilities. With regard to care, the idea of equality is crucial in order for the care practice to not slip into a paternalistic relationship. This is actually one of the concerns behind the refusal of institutional care as a full-fledged alternative to informal family care. However, the notion of equality is also crucial when discussing care so that the abuse and vulnerability of care workers, who are paid little and implicitly expected to make some sacrifice, can be prevented.

Primarily, care is a social responsibility rooted in fundamental social interconnectedness and interdependence. According to Tronto, through caring responsibility it is possible to look not only at gender inequalities but also on social inequalities and the distribution of privileges in society (Tronto, 1994, p. 164). That is why it is fundamental to analyse both care provided to people and the conditions under which care workers carry out their work (Uhde, 2018). Tronto points out that the existing social structures allow privileged groups to ignore the needs and hardships of others in favour of meeting their own needs, which she calls privileged irresponsibility that also serves to maintain the status quo and undervaluation of care (Tronto, 1994, p. 174). Inequalities in care relations relate to class and gender inequalities, but also to inequalities embedded in ethnicity-based and/ or nationality-based structures of disadvantage. Furthermore, unequal access to care and the satisfaction of needs leads to the reproduction and deepening of other inequalities in society.

While caring responsibility can be expressed as a universal principle, the care practice cannot be separated from particular relations of care. Therefore, Tronto emphasizes that caring institutions need to respect people's different preferences and needs, and create space for individualised care without undue submission to the dictate of a unified norm.

${ }^{4}$ Here, Tronto does not use the term asymmetric reciprocity elaborated by Iris Young (1997); however, both authors work toward the same principle of incommensurability of perspectives and the impossibility of drawing from one's experience general inferences about the experience and needs of the other. 
This is a major challenge for the setting up of caring institutions that need clear-cut rules and decision-making and responsibility structures but they must also be based on attentiveness and responsiveness toward individual care needs that require contextualized decision-making and a pluralistic understanding of care (cf. Bourgault, 2017). Although it may seem intuitive, inferring norms of institutional care from the normative notions of family care does not provide an adequate foundation of principles of caring institution. On the other hand, the market model of social relations may not contribute to providing quality care, either. Tronto (2010) stresses out that market relations are not necessarily a suitable model for setting up caring institutions. Market relations are not organized according to needs, but according to resource ownership, and within those, the individual is reduced to an individualized consumer, which is inconsistent with the holistic understanding of the care practice. Furthermore, the relationship between the consumer and the service provider is unequal given the nature of the exchange. For Elizabeth Anderson, however, the decisive distinction is not whether a relationship involves a transfer of money or not, but what norms determine the specific activities (Anderson, 1993). When applied to care, care then becomes a commodity if its distribution and provision is determined by profit-oriented market values. It is the institutional framework of the market, not the presence of money as such, that creates the negative consequences of the transfer of money in care relationships in the form of the commodification of care (Ungerson, 1997). Within the market, everything receives its price only instrumentally, which does not allow for full appreciation of care in all its aspects. Whilst the market can play a positive role in allocating some goods and organising some relationships, the society must delineate the limits of the market in areas such as health care, education, childcare and eldercare.

The commodification of care must be analysed on two levels: the first level has to do with the issue of the commodification of the characteristics and/or the entire personality of the care worker, respectively, the second involves the issue of the commodification of motivations (see Uhde, 2012). The first level touches upon a more general question of the commodification of wage labour in the capitalist system, where the personality of the worker becomes the object of the market exchange as well. Since care is situated in inequality structures, receiving low-value and precarisation status within the labour market, the commodification of care promotes an instrumentalised approach to care workers as a means to meet the needs of others. The care needs of the latter, whether synchronous or supposed in the future, are sidelined.

The second level concerns the motivation of the care workers. Regarding this issue, Margaret Jane Radin (1996) refers to the process of incomplete commodification. According to her, people maintain at once a commodified and a non-commodified notion of a given activity. The care workers thus have both instrumental commodified motivations in the form of money and non-commodified motivations to provide quality care with regard to a care-receiver's well-being. Although this has been confirmed in our research, Radin's argument is not complete since the pressure to increase efficiency and performance in eldercare institutions that are driven by market norms-including 
public institutions whose care provision is gauged against a market efficiency criterion by health insurance companies, for example-restrains the possibility on the part of the care workers of applying any non-commodified motivations. The commodification of care thus leads to the reduction in the quality of care, as the market norms put at the forefront values that are inconsistent with the values of care.

\section{Public eldercare policies in the Czech Republic}

Although there is diversity in the provision of eldercare across European countries (cf. Da Roit, Le Bihan, 2010), it also holds that in spite of these diverse institutional contexts and specific regulations, one can identify within eldercare a common development trend, characterized by deinstitutionalisation and marketization of care (Österle, 2010; Kubalčíková, Havlíková, 2016), reflecting the principles of the so-called new public management, such as individualisation, pluralisation, decentralisation and privatisation. This is presented as a way to establish a new balance between the growing need to provide care for an increasing number of older people (not only) in European countries (cf. Colombo et al., 2011), and financial constraints on welfare spending. The market-oriented policies of eldercare actually result in deviating from residential care in institutions to home care, reducing public financial support, and growing reliance on market mechanisms that are supposed to secure the missing funds (Ranci, Pavolini, 2013).

The process of institutionalisation of eldercare occurred in the Czech Republic, as in other real-socialist countries, earlier than in many other European countries. The orientation of eldercare politics in this direction was guided by the intention of liberating women from the demanding care in the family and freeing female labour force. However, the model of residential eldercare set up in Czechoslovakia in the 1950s was characterized by a directive style and paternalistic attitudes towards older people, insufficient availability of formal care, and providing care on a medical rather than a social basis with little respect for people's needs other than health and physical ones. Even at this time, informal care in the family represented a substantial part of eldercare. From the mid-1960s onward, partial measures were introduced to support care for older people in their home environment, such as field day care services, and consequently an attendance allowance for persons caring for close relatives (Maříková, Plasová, 2012). Therefore, the origins of de-institutionalisation of care in the Czech Republic can be found already prior to 1989.

People's attitudes to residential eldercare facilities during real socialism were ambivalent. On the one hand, these facilities were in demand as is shown by a formidable long-term overhang of demand over supply. However, this interest was partly due to the generally low availability of other eldercare alternatives. On the other hand, people adopted a critical attitude toward eldercare institutions on account of the lack of respectful care, and the preference for eldercare in the home setting provided by the family, or more precisely, by women relatives gained traction (Kasalová, 1988). 
With the 1990s economic transformation, eldercare policies began to be guided through partial measures toward what was witnessed in some Western European countries back in the 1980s, particularly the individualisation of care and efforts to increase its "economic efficiency". Initially, residential eldercare provided in health facilities (so-called medical institutions for the long-term ill) was scaled down. This was accompanied by a drop in state support for other residential eldercare facilities which were seen as too costly, as opposed to home care (cf. Průša, 2009). Next, a range of possible formal care providers was extended to non-state actors (notably churches, non-profit organisations, private companies) (Mař́ková, Plasová, 2012).

It was the 2006 Social Services Act which ushered in a significant change to eldercare. Behind the adoption of this law was an effort to strengthen the deinstitutionalisation of eldercare, ${ }^{5}$ to transfer care to non-state actors and to introduce market mechanisms in its provision and functioning (Důvodová zpráva, 2005). One of the main stated aims of this law was the promotion of individualized care as opposed to unified residential eldercare, along with the empowerment and autonomy of eldercare clients.

Similarly to some other European countries (Roit, Le Bihan, 2010), a cash-forcare benefit was introduced in the Czech Republic, it is paid directly to the beneficiary (not the care worker). The use of this benefit is limited to cover a provision of care and the beneficiary is obliged to prove that the allowance has been used to secure the care assistance (in case of informal care a verbal declaration is usually considered to be sufficient). According to the statistics, in 2012, only $18 \%$ of beneficiaries used the benefit to buy care services exclusively from registered care providers (Hubíková, 2012). At the same time, flat-rate subsidies from the state budget earmarked for social service providers, such as a bed allowance for residential care providers, were annulled. Subsidies ceased to be claimable and are distributed by the respective regions' decisionmaking bodies to the registered providers of eldercare who apply on a yearly basis. The residential facilities established directly by the regions receive on average higher subsidies (Statistická ročenka, 2016). The amount of public subsidies for social services, though, is not stable and depends to a large extent on the actual constellation of the political representation.

The entire eldercare system is permanently in a state of uncertainty and underfinancing. On the one hand, a competitive environment amongst different providers is promoted, while on the other hand, with a view on protecting older persons, maximum prices are set for the provision of care services both in field and residential care. Eldercare thus works in a quasi-market environment that is based on market principles. It defines care relations as those between a consumer and a provider, while setting certain financial limits

5 In this context, the law distinguishes field care services (pre-arranged tasks during a preagreed period of time, restricted by regular working hours) and personal assistance that provides a wider range of care services to suit the needs of people also out of their homes throughout the whole day, and it is paid on an hourly basis. Field services also include in-home medical care the provision of which is covered by health insurance and is subject to medical recommendation, while it is performed by nurses. 
for care services. For field care, an hourly rate of care is set as well as a rate for individual procedures. ${ }^{6}$ If people live in a retirement home, the full care allowance granted to them is legally due to the provider of registered residential services. On top of that, older people also pay for accommodation and meals, for which there are also price-caps. ${ }^{7}$ Most older people in residential care cannot cover with their retirement pension the total cost of the residential fee, and for the majority of people, the care allowance does not cover the costs of the care provided, either (Průša, 2013; Valová, Janebová, 2015). This gives rise to a deficit that needs to be paid from public subsidies to social services. It is precisely because of the administrative burden of applying for subsidies and the uncertain granted amount that this quasi-market environment operates according to the principle of a selffulfilling prophecy: the setting up of a financially unsustainable system then as if inevitably leads to the annulment of rules restricting the free market of care.

The model of funding of residential and field eldercare increases, largely in nonprofit organisations, the pressure to raise funding from other sources apart from clients' payments. This aggravates the administrative and time-related demands of managerial work, since it is necessary to apply (in fact compete) for non-claimable subsidies from various public sources and to look for other financing options (Valová, Janebová, 2015). The setup of some funding rules (such as the allocation of state subsidies on a one-year basis only, with the first money usually reaching organisations after a several months' delay, etc.) does not allow for long-term planning in terms of funding for institutions and eldercare services. In a situation where non-profit organisations are not legally permitted at the same time to transfer funds to the next year, there is a significant deficit in their financing at the onset of each year. However, the uncertainty and the financial deficit in the area of provision of formal care formed a political pressure, following the adoption of the new law in 2006 that has led in recent years to the bolstering of the public finances earmarked for social services (including eldercare).

Changing the funding arrangements of the eldercare system in favour of its quasimarket organisation and the application of efficiency and reportability has led to many unintended consequences, particularly in the area of formal care. It has impacted not only the working and wage conditions of formal care workers, but also the ability of care-providing institutions to fulfil, under the given conditions, the ideal of quality care. Ultimately it also has an impact—-to a varying degree—on the notions of the ideal of quality eldercare on the part of individual agents.

6 In 2017, the upper limit per hour of provided care was CZK 130 (approximately EUR 5). The care allowance was sufficient to buy, as a maximum, up to 6 hours of field services a month for the $1^{\text {st }}$ stage of infirmness, for the $4^{\text {th }}$ stage up to 101 hours a month.

7 In 2017, the maximum cost was CZK 11,780 per month (approx. EUR 453), but 15\% of the pension had to remain available to its recipients even if it meant $\mathrm{s} / \mathrm{he}$ could not pay a given price. The average pension was CZK 11,807 (approx. EUR 454), while 60\% of older people received lower ones. 


\section{Methodological approach: interviews with care workers and experts in eldercare}

Our empirical research is based on feminist theory of care that emphasizes the interconnection of practice, normative concepts and values associated with care. The collective notions of care and the care practice are socially enacted in relation to social institutions and historical processes, which have a material impact and affect individuals' behaviour, and at the same time they are shaped and reproduced by their actions. In contrast to the commonly applied approaches in qualitative social science research, we link in our research social constructionism with a critical realist approach to social ontology (Elder-Vass, 2012; 2015). In formulating his approach to realist social constructionism, Dave Elder-Vass assumes that "social construction depends upon real causal processes that depend on the materiality of the world we live in and that we should strive to identify and analyse them" (Elder-Vass, 2012, p. 265).

This epistemic perspective makes it possible to examine everyday care practices and how care workers, representatives of care providers as well as experts perceive it, both given the normative notions of caring - the criterion of which today is to a large extent the ideal of home care, since the holistic approach to caring seems intuitively to be compatible with it-and given the social structures and institutions in which the bureaucratic setting of public care policies meets the market-oriented notion of how care is organised. In this way, the goal of the research is to capture the real impact of changes in care policies across the different segments of formal care in the Czech Republic from a point of view of differently situated individuals. It the analysis of their narratives we then focus on a hermeneutical interpretation of the normative overlaps of the current practice for caring institutions.

In our research, we work primarily with the analysis of semi-structured interviews (Wengraf, 2002) carried out with 19 experts working at different levels of the eldercare system in the Czech Republic, ${ }^{8}$ and 29 care workers who work in residential facilities and/ or provide field care and health services. ${ }^{9}$ These communication partners mainly included women (27 women) of different ages, educational backgrounds as well as various private life arrangements, working in Prague and other regions of the Czech Republic. They were active in various types of field and residential social and health care services established by regions, municipalities, and/or non-profit organisations.

Qualitative data from interviews were analysed in accordance with the principles of the thematic analysis (Guest et al., 2012). It traces explicit and implicit meanings and formulas that are interpreted through coding and are assigned a meta-meaning (Braun, Clarke, 2006). In our analysis, we focused on the inner similarities and differences of the accounts

8 I. e. ministerial officials, a representative of the trade union's health and social care department in the Czech Republic, representatives of civic and professional associations specializing in long-term eldercare, heads of various types of organisations providing eldercare.

9 We conducted the interviews between July 2016 and April 2017. 
included under individual codes, which enables a new understanding across the individual communication partners' accounts, and a hermeneutics-based interpretation of the lived critique on the part of the actors and the normative overlap contained in these accounts.

\section{Limited space for a holistic care practice}

In the interviews with the representatives from amongst care providers on all levels, what stands out is the ever re-surfacing description of the tension between what they thought should be done in order to provide the best care possible and what is realistic to accomplish with scarce resources within an inherently incoherent network of rules of public care policies, as we in detail presented elsewhere (Maříková, 2019). The positive intentions, or in Jane Radin's words (1996), the non-commodified motivations of eldercare providers and care workers, were confronted with the consequences of the trend toward market-oriented organisation of care facilities, as well as with the malfunctioning rules focused on division of responsibilities amongst different actors and different types of institutions involved in providing eldercare (e.g. hospitals vs. nursing homes, health vs. social care financing, individual vs. social responsibility, market-driven approach vs. public support of care).

The transfer of a significant part of the funding from the public support for eldercare to care allowance, which is designed as an individual benefit, is assessed by the providers of field and residential services ambivalently. On the one hand, they considered it a positive measure which gives greater opportunities to older people to materialize their ideas of care. They associated the unintended consequences of its introduction with the overall framework of public policies of eldercare in which a care allowance is only one of many elements. On the other hand, some eldercare providers perceived it reservedly, or even negatively, as its introduction caused major complications to organisations providing eldercare, especially with regard to their long-term planning and the development of these organisations. From the accounts of our communication partners it is clear that retirement homes incur deficits due to the discrepancy between the real costs of care and the different amounts of the care allowance granted to particular persons. Additional funding must then be sought from state subsidies for social services and from other sources (cf. Valová, Janebová, 2015). Notwithstanding the price-caps set for care services, some private residential services agencies then use their soft power vis-à-vis older people's relatives who are dependent on the provision of formal care for their relatives, and charge supplementary fees for a number of personal hygiene aids or care services that are defined as complementary (leisure activities, rehabilitation and exercises, etc.). Depending on the level of public subsidies on social services, providers of field services must put a limit on the services offered irrespective of care needs (e.g. an increasing need for care due to a progressive illness, new applicants for formal home care, etc.).

According to providers of eldercare in our research, the underfinancing of formal eldercare services, along with the uncertainty of their funding, particularly in the case of non-state service providers, directly and indirectly negatively affects not only the 
possibility of providing quality eldercare (infrastructure investment planning, better availability of single rooms and privacy for older people, stable and sufficient number of care workers, etc.), but also the ability to flexibly respond to the real needs of care in society. The continuing uncertainty of funding works directly against efforts to clearly define the purpose of eldercare, which should be one of the pillars of caring institutions.

Our communication partners were also critical of some rules of public care policy, which ultimately hinder the original intention of the reforms to bring closer caring and nursing (health sector) practices. One of these rules is the strict separation of the funding for social and health care, these being funded from the budgets of different ministries, which is coupled with separate reporting systems. According to them, when it comes to the eldercare system such a division is often meaningless and counterproductive, which they were able to support by numerous examples. For instance, care workers in retirement homes may not perform certain "medical" procedures, not even those which are quite commonly carried out in the case of family care, namely applying medication. Directly inconsistent with the efforts to provide high quality care is then the necessity of transferring to hospital the cases that could be addressed in residential facilities. Other hindrances might be caused by the problematic collaboration with general practitioners ${ }^{10}$. The care providers at all levels felt that the strict division of care and health care reinforces a fragmented and reifying approach toward older people in need of care apart from the fact that it further increases the deficit in the organisations they administer. The fact that payments from health insurance companies are not reimbursed within the set deadlines and some of them are not paid at all increases the economic uncertainty of many eldercare facilities and services.

Our communication partners therefore reflect on the fact that due to the inadequate setup of rules and the underfunding of the eldercare system, the services provided are not provided in a sufficient scope and quality. Some representatives of non-governmental organisations providing eldercare especially in Prague then claim deregulation of prices for provided residential and field care as a solution. They rely on the assumption that "their clients" (and their families) are affluent enough to finance the provided services at significantly higher price levels than up until today.

It becomes apparent here that the quasi-market setting of the eldercare leads individual actors to promote the commodification of care, nonetheless without any reflection of other unintended consequences that disrupt the holistic care practice-including the nurturing of a social environment of trust in that care will be provided to all which constitute the caring-with stage (Tronto, 2013). While the representatives who spoke in favour of price deregulation did not intend denying access to care for older people who lack sufficient financial resources, they suggested creating a multi-level quality care system. From the

10 E. g. the communication partners pointed out that the medical procedures are not prescribed by the GPs to the extent necessary for those who need it. At the same time, they are under pressure from health insurance companies, which set the limits for drug prescriptions for GPs in order to reduce costs. When these limits are exceeded, GPs face financial sanctions by health insurance companies. 
point of view of the ethics of care, this standpoint is morally disputable; however, such an approach reflects the social relations in late capitalist societies. Some also explicitly claimed the splitting up of residential facilities based on the social background from which older people come from, justifying it with a reference to different demands in terms of standards' expectations and lifestyle.

While this proposal seemingly adheres to the principle of the right to care for everyone, the legitimation of double norms of good care according to one's social status and class reproduce the existing social inequalities and are the expression of privileged irresponsibility (Tronto, 1994). Moreover, even now, according to our communication partners, $70 \%$ to $80 \%$ of their clients cannot afford to pay the full (statutory maximum) charge for provided accommodation and meals. However, even the current system is not entirely universal, because the care allowance, in particular at lower tiers, is insufficient, and older people with the lowest retirement pensions fall through the care provision social networks. In practice, they have only limited possibilities to seek refuge in "rooming houses for the poor older people" that provide care without registration. ${ }^{11}$

\section{Two sides of care vulnerabilities}

Despite empirical evidences of the negative consequences of the introduction of market principles and taylorisation of care work (Meagher et al., 2016; Barbieri, Sarti, 2016), public care policies in Europe still more or less keep promoting this trend, which tends to be regarded as a remedy for the chronic lack of finances in the area of public support for care and the deficit of care which is particularly noticeable in eldercare. Our communication partners who work as care workers more or less confirmed the findings of other research studies. In the following part, though, we will focus on the analysis of the interrelationship of the negative aspects of the working conditions of the care workers and the care provided by them. These two levels are often addressed separately in care policies. If we look at care-receivers, or their relatives respectively, as consumers who buy care services, the perspective of the care worker is left aside. And if we look at care work in an undifferentiated way as any other work, the mutual relationship between the care worker and the care-receiver disappears from the field of vision. A holistic view of care practice reveals not only how the two aspects are related, but also what role the idea of equality plays in caring institutions.

When it comes to the actual practice of care provision, the two sides facing and interacting with each other are two groups of people marginalized within the social structures in a different manner. On the one hand, older people who are dependent on the assistance of others, and on the other hand, care workers whose work is defined as low-skilled and receives a very poor salary. Some representatives of non-profit providers assessed negatively the setting of price-caps for individual care services that they may ask

11 Here, the care is usually provided to older people with the lowest incomes who are in a dire economic and social situation. For more information, see a case study (Kubalčíková, Havlíková, 2016) and an Ombudsman’s Investigation Case (Veřejný ochránce práv, 2014). 
from older people for providing care. They saw as a solution the deregulation of the prices for provided care. However, they lacked the ability to critically reflect precisely on this dual vulnerable position in caring relationships, without which one cannot even begin to try to close the circle of care provision from the societal and long-term perspective, one which Tronto (2013) describes as the fifth stage of caring-with, and the basis of solidarity and trust within society. Since care is so poorly rewarded, care workers themselves would not be able to afford to pay the market prices for eldercare later in their lives because they themselves do not have enough to save up, and because they will end up receiving a very low retirement pension. This only proves the privileged irresponsibility, where neither the care needs of those who provide care are taken into account nor they are recognized for providing care to others. The pressure to reduce the cost of care is negatively passed on to care workers who are often forced, particularly in field assistance and/or health services, into non-standard forms of work without a full social security (agreements to perform work, work on a trade licence) and without the right to reimbursement for the time spent commuting between clients' households. Also, payments by health insurance companies (in cases of field health care) tend to come in late. Changes or delays in the payment of public subsidies on social services, which cause cash flow problems to organisations, are offset by the delays and reductions of wages paid to employees. However, the pressures on cost reduction are also passed on to older people; for example, care visits get shortened in the field home care in order to allow for transfers or to make up for an insufficient number of care workers due to high staff turnovers and precarious forms of employment.

Given the perception of the working conditions and the opportunities of providing care that care workers consider to be good, there is a difference between residential facilities (retirement home, home with a special regime) and field home care (care and personal assistance services). In both cases, however, a lack of time was a prevalent significant negative factor, making a holistic understanding of care impossible. While in residential facilities care workers emphasized as downsides the lack of an intimate space, and the impossibility of individually organising the daily regime of older people based on their preferences, and the taylorisation of work underscored by a small number of care workers, they appreciated working in a team and the possibility to consult others whenever problems or ambiguities arise, for example, in connection with their client's health condition. The communication partners employed in residential facilities mentioned the possibility of taking a leave of absence or staying at home due to sickness or because they need to take care of sick children as one of the key benefits over field care work with which many of them had had some previous experience. Nevertheless, their evaluation largely depended on the management's approach toward care workers and the organisation of work. Being treated as equals and competent actors was crucial for the care workers' satisfaction. In contrast, what stood out as drawbacks in field care services was the solitary nature when it came down to complex health decisions at any given moment or in specific disputes, the time-consuming transfers between clients' households (which are not always paid), a greater degree of the precarisation of work, and a contrast between the intimacy of home environment and the uniform timing of fragmented care procedures. Most field 
care workers, however, saw in a positive light that their work enabled older people to stay at home for a much longer period of time. Though they could feel the loneliness of older people, they took care of.

Most of our communication partners struggled with insufficient income to make their ends meet. Even if they do not live together with a partner or husband, for the better part they share a household with someone else (roommates, relatives, etc.). The economic marginalisation is also reflected in how some women have a negative perception of their strong dependence on their partners, and how this reinforces gender inequalities in partnerships and within society as a whole through the institutionalising of the feminisation of poverty. And yet, it was clear from these accounts that most of the care workers, who still put their salary expectations, perhaps surprisingly, below the average wage, relate these expectations to the fact that they take care of older people who are not well-off, and that they work in an area where there is a visible lack of resources at all levels. ${ }^{12}$ At the same time, low wages are seen by many communication partners as one of the material reasons for a minor representation of men among care workers in day-to-day care.

A persistent shortage of care workers also makes this profession the way out of unemployment for women with higher qualifications in other fields. To work as a care worker, a relatively short training course is sufficient. All of our communication partners stressed that it was the meaningfulness of eldercare which eventually brought them to this work. And save for some, they also reflected on the limited work opportunities they had in the labour market. This reinforces the vicious circle of public care politics based on the definition of care as a low-qualified, hence-for seemingly legitimate reasonslow paid work, implicitly identifying caring competencies with "female" abilities, which ultimately also serves as a justification for the strict division of the partial procedures of formal care that can only be exercised either by care workers or nurses. However, for eldercare, which by its very nature requires continuous securing of social and health care, such a fragmentation of the provision of care has a negative impact both on the functioning of care institutions and the quality of provided care, which should be guided by care needs in time when these emerge. A number of tasks in day-to-day eldercare do not require full medical education, and in practice, this strict separation of personnel must often be circumvented in order to ensure the smooth functioning of eldercare institutions. However, this rigidity, which is at first glance of seemingly bureaucratic nature, is not inherent to the bureaucratic organisation as such. It is rather driven by economic pressures to minimize the cost of reimbursing the provision of health care from older people's public health insurance, and to maintain low wages in care work compared to medical personnel. Health insurance companies are influential power stakeholders here which shape care policies. As a result, this strict separation of health and social care prevents or complicates

12 After completing our field research, there was an increase in social services wages, but still a care worker's wage does not reach the average wage. In mid-2017 the average care worker's wage was CZK 20,304 (EUR 781) compared to the average wage of CZK 29,346 (EUR 1,129) (cf. ISPV II/2017, Chválová, 2018). 
to some older people the procurement of home care, which is defined-by the declared care policies_-as a preferred option.

All care workers, regardless of whether they work in residential facilities and field care services, criticized the fact that care must be limited to the performance of mechanical tasks (food, hygiene, minor tidying), while there is no time left for the interaction with a human being, which all of them saw as an essential and integral part of a care practice. Restricting care to mechanical tasks goes hand in hand with the Taylorism of work, with care being fragmented into standardised time bits that certain tasks are expected to take. As the care workers reflected, there is no room left for taking into account older people's individual needs and competences (Maříková, 2019). Although in public discourse this is often largely attributed as a drawback to retirement homes, older people living alone in their homes are often a lot more lonely and the pressure on time efficiency and the reportability of partial tasks performed in care services and home medical care is all the greater. The existing shortage of care workers also increases the intensity of work, which by itself is very demanding physically and psychologically, and which gets increasingly complicated with the increase in administrative burden that the communication partners report having witnessed in the past few years. This has to do with administration, on the one hand, that is justified by the need of reportability and transparency, and also new administration driven by efforts to provide individualized care. The effort to provide individualised care which was viewed positively by the care workers in retirement homes, often end up being their "homework" after work hours. In contrast, the trends towards greater reportability (scanning barcodes for partial tasks provided to individual clients) were rated negatively by the care workers. The reason cited by them was that these procedures transform the intersubjective relations of care into market and depersonalized consumer-provider relations.

\section{Conclusion: ideas of caring institutions from practice}

In the past, the institutions of eldercare were often characterized by a bureaucratic organisation of care, which in practice led to the provision of depersonalized and paternalistic care bound by rigid rules. In contrast, the ideal of home care in a family setting was maintained as the only option, which could fulfil the holistic care practice in the sense of closing the circle of all five stages of care as identified by Joan Tronto (2010). In late modern society, however, one cannot expect that the growing care needs of older people will be fulfilled within family relationships. Formal eldercare constitutes a necessary pillar of public care policies and the basic pillar of meeting social responsibility for care. Reflections on how to translate the principles of a caring institution into a particular practice thus become a crucial issue for public care politics and society as a whole.

The reforms of public care policies in the Czech Republic, which accompanied the capitalist transformation and were based on the principles of the market-inspired organisation of care, supported by a cash-for-care benefit, aimed to create a space for providing individualized and economically efficient formal care. However, these changes 
did not result in intended improvements in the end. Marketized care is, in practice, subject to the principle of profitability, where individualized care is provided to paying customers. The market-inspired changes in eldercare, however, transformed also the public care sector, which is now characterized by the growing emphasis on cost-effectiveness and costaccounting, the fragmentation of care into partial tasks according to a pre-set schedule and an increasing pressure on the performance on the part of care workers. These tendencies go directly or indirectly against the efforts of individual actors to provide quality care tailored to older people's individual needs and expectations.

In the Czech Republic today, the model of eldercare funding is built on a quasi-market environment. On the one hand, it supposes the financing of the care system along the lines of the customer-provider relationship; on the other hand, it still maintains the principle of egalitarian access to care by setting price-caps for the provided care services. The resulting deficit between the financial means of older people, who are one of the groups most vulnerable to poverty in the Czech Republic, and the real cost of care is partly offset by public subsidies to social services, which however are non-claimable and unstable. The public care policies in the Czech Republic thus essentially institutionalize the conditions of a self-fulfilling prophecy where the uncertainty of funding coming from the public budget leads some non-state eldercare providers to claim the full opening of the eldercare sector to the market principles. However, the deregulation of prices of care services would very likely lead to the deepening of the current trend to legitimise the double standard of good care according to the social status and class. In this sense, the current system of funding public eldercare not only does not promote a redefinition of residential care facilities in accordance with principles of caring institutions which we explained earlier referring to the work of Joan Tronto (2010; 2013), it also exacerbates age-based social inequalities.

In the accounts of the care workers and the representatives of care providers whom we interviewed, there is a tension between the efforts to provide the highest quality care and the limited possibilities. They formulated their notions of good care literally in defiance of the limitations due to the lack of financial resources and some rigid rules. Against this backdrop, we identified the normative overlaps which, according to the actors with direct care experience, should constitute the foundation of caring institutions. Greater financial support to eldercare institutions from the state was viewed as a necessary but not sufficient condition by all communication partners. But money alone is not a panacea for all problems. Financial security was perceived more as a condition for the implementation of innovative ideas and strategies to fulfil the care need of individual older people.

Most of our communication partners viewed positively the settings of the standards of care and of the mechanisms of control by the state. They reflected on this in particular with regard to the vulnerability of older people who are dependent on care. At the same time, however, they criticized the fact that the current set of rules does not allow for a creative approach to improving the quality of care, which would require more time to be spent with a particular individual as well as the option of a more flexible division of labour within an organisation (for example, greater substitutability of nursing staff by caring staff and vice versa). However, in the eldercare practise care workers encounter a number of 
unexpected and complex situations with regard to the health condition and/or complicated behaviour on the part of older people, and so a clear division of job responsibilities was also formulated as an important principle of providing quality care. Given that eldercare is very demanding psychologically and physically, caring institutions must also ensure friendly working conditions. Their superiors' recognition of the work they perform was also very important for care workers. Our communication partners also viewed positively the possibility of working part-time. Though only very few of them could afford to make use of that because of low wages. This aspect should then be taken into account in caring institutions as well. In order to fulfil the idea of equality in care relations, it is necessary to create an environment that will alleviate people's vulnerability on both sides of the respective care relations, that of older people and care workers.

General wisdom has it that institutional care is considered to be worse than the care provided to people in their home environment. However, the experience with the work in residential facilities did not necessarily lead the care workers to rejection of care facilities. On the contrary, about half of the care workers we interviewed said that they would not want to put the burden of this demanding care on their families and that they would prefer to be taken care of in a "nice facility". Still, some of those who preferred to be taken care of in retirement homes considered procuring care for their relatives (mostly parents) in the home setting. There appears to resurface here once again a general shared concern regarding care institutions, which in their minds, however, can be an environment for providing individual and sensitive care, supposing they are built on an accommodating approach toward both older people and care workers. Nonetheless the practice still lags behind this potential.

\section{References}

Anderson, E. (1993). Value in Ethics and Economics. Cambridge: Harvard University Press.

Barbieri, N. A., Sarti, C. (2016). Too much love: institutional care for old age, VibrantVirtual Brazilian Anthropology, 13(1) Available from: http://dx.doi.org/10.1590/1809-43412016v13n1p071 (Accessed September 3, 2019).

Bourgault, S. (2017). Prolegomena to a Caring Bureaucracy. European Journal of Women's Studies, 24(3): 202-217.

Braun, V., Clarke, V. (2006). Using Thematic Analysis in Psychology. Qualitative Research in Psychology, 3(2): 77-101.

Chválová, J. (2018). Financování a platy a počty zaměstnanců v sociálních službách v letech 2015 až 2017. Available from: http://www.zdravotnickeodbory.cz/cz/clanky/1-6-2018-socialni-sluzby-statistika.aspx (Accessed: 10 October, 2019)

Colombo, F. et al. (2011). Help Wanted. Providing and Paying for Long-Term Care. OECD Health Policy Studies, OECD Publishing.

Da Roit, B., Le Bihan, B. (2010). Similar and Yet So Different: Cash-for-Care in Six European Countries' Long-Term Care Policies. The Milbank Quarterly, 88(3): 286-309. 
Dudová, R., Vohlídalová, M. (2018). Muži a ženy pečující o seniory v rodině. Sociologický časopis / Czech Sociological Review, 52(2): 219-252.

Di̊vodová zpráva k zákonu č.108/2006 Sb. o sociálních službách (2005). Available from: https://www.vlada.cz/assets/ppov/lrv/ria/databaze/Zaverecna-zprava-RIA-k-novelezakona-o-socialnich-sluzbach.pdf (Accessed: 11 October, 2019)

Elder-Vass, D. J. (2012). The Reality of Social Construction. Cambridge: Cambridge University Press.

Elder-Vass, D. J. (2015). Developing Social Theory Using Critical Realism. Journal of Critical Realism, 14(1): 80-92.

Guest, G., MacQueen, K. M., Namey, E. E. (2012). Applied Thematic Analysis. Los Angeles: Sage.

Held, V. (2006). The Ethics of Care. Personal, Political, and Global. Oxford: Oxford University Press.

Hubíková, O. (2012). Př́mé platby za péči v kontextu nevyjasněného status neformální péče. Sociální práce / Sociálna práca, 4(12): 113-125.

ISPV (2017). Informačni systém o průměrném výdělku (II/2017). Available from: https:// www.ispv.cz/getdoc/b33a5c7c-ae91-4e1f-a301-c84984d99373/Aktualni.aspx (Accessed: 10 October 2019)

Kasalová, H. et al. (1988). Životní situace starých občanů. Zpráva z výzkumu. Praha: VÚSRP.

Kubalčíková, K., Havlíková, J. (2016). Current Developments in Social Care Services for Older Adults in the Czech Republic: Trends towards Deinstitutionalization and Marketization. Journal of Social Services Research, 42(2): 180-198.

Maříková, H. (2019). Nadějné vyhlídky? Péče o starší z perspektivy osob pečujících ve formální péči. Fórum sociální politiky, 13(2): 9-14.

Maříková, H., Plasová, B. (2012). Kontinuita nebo změna v systému zajištění péče o seniory v České republice od roku 1948 vzhledem k genderovanosti politik péče. Fórum sociální politiky, 7(3): 2-7.

Meagher, G., Szebehely, M., Mears, J. (2016). How Institutions Matter for Job Characteristics, Quality and experiences: A Comparison of Home Care Work for Older People in Australia and Sweden. Work, Employment and Society, 30(5): 731-749.

Österle, A. (2010). Long-term Care in Centrals and South-Eastern Europe. Challenges and Perspectives in Addressing a 'New Social Risk. Social Policy and Administration, 44(4): 461-480.

Průša, 1. (2009). Je nový systém financování sociálních služeb pro staré občany efektivní? Národohospodářský obzor, 9(3): 141-156.

Průša, 1. (2013). Ekonomická efektivita zajištování péče o př́jemce př́ispěvku na péči. Praha Available from: https:/www.socialnaspolocnost.sk/wp-content/uploads/2014/04/Ekonomick\%C3\%A1-efektivita.pdf (Accessed 10 October, 2019)

Radin, M. J. (1996). Contested Commodities: The Trouble with trade in Sex, Children, Body Parts, and Other Things. Cambridge: Harvard University Press. 
Ranci, C., Pavolini, E. (2013). Reforms in Long-Term Care Policies in Europe: Investigating Institutional Change and Social Impacts. New York: Springer.

Ruddick, S. (2002); [orig. 1989]. Maternal Thinking. Towards a Politics of Peace. Berkeley: University of California Press.

Statistická ročenka z oblasti práce a sociálních věcí (2016). Praha: MPSV.

Tronto, J. C. (1994). Moral Boundaries. A Political Argument for an Ethics of Care. New York: Routledge.

Tronto, J. C. (2008). The Ethics of Care: Personal, Political, and Global (review). Hypatia, 23(1): 211-217.

Tronto, J. C. (2010). Creating Caring Institutions: Politics, Plurality, and Purpose. Ethics and Social Welfare, 4(2): 158-171.

Tronto, J. C. (2013). Caring Democracy. Markets, Equality, and Justice. New York: New York University Press.

Uhde, Z. (2012). Autoritářství trhu: kritická diagnóza deformované emancipace žen. Filosofický časopis, 60(1): 55-76.

Uhde, Z. (2018). Caring Revolutionary Transformation: Combined Effects of a Universal Basic Income and a Public Model of Care. Basic Income Studies, 13(2): 20170019. https://doi.org/10.1515/bis-2017-0019.

Ungerson, C. (1997). Social Politics and the Commodification of Care. Social Politics, 4(3): 362-381.

Valová, H., Janebová, R. (2015). Antiradikálnost” českých sociálních služeb aneb jak organizace sociálních služeb řeší pokles finančních prostředků. Sociální práce/ Sociálna práca, 15(1): 5-23.

Veřejný ochránce práv. (2014). Kritická zjištění ze systematických návštěv pobytových zařizení pro seniory bez oprávnění k poskytování sociálních služeb. Brno: KVOP.

Wengraf, T. (2002). Qualitative Research Interviewing: Biographic Narrative and Semi-structured Methods. London: Sage.

Young, I. M. (1997). Asymmetrical Reciprocity: On Moral Respect, Wonder, and Enlarged Thought. Constellations, 3(3): 340-363.

Young, I. M. (2007). Recognition of Love's Labor. Considering Axel Honneth's Feminism. In: B. van den Brink, D. Owen (eds). Recognition and Power. Axel Honneth and the Tradition of Critical Social Theory. Cambridge: Cambridge University Press.

\section{Streszczenie}

Artykuł dotyczy zinstytucjonalizowanej opieki nad osobami starszymi (w formie usług stacjonarnych i środowiskowych), ze szczególnym uwzględnieniem Republiki Czeskiej jako jednego z byłych krajów socjalistycznych. Po transformacji kapitalistycznej w Czechach nastąpiła znacząca transformacja systemu opieki nad osobami starszymi. Towarzyszyły jej jednak stosunkowo egalitarne postawy i oczekiwania społeczne. Artykuł czerpie z badań jakościowych opartych na wywiadach z pracownikami świadczącymi usługi opiekuńcze 
oraz ekspertami pracującymi na różnych szczeblach systemu opieki nad osobami starszymi w Czechach. Nasza analiza opiera się na feministycznej teorii opieki, która pozwala nam krytycznie zastanowić się zarówno nad zmianami, jak i niezamierzonymi konsekwencjami konstrukcji polityki opiekuńczej, a także opiniami badanych na temat tego, jak zapewnić opiekę wysokiej jakości. Naszym celem jest identyfikacja aspektów systemu, które są pozytywnie postrzegane i które z punktu widzenia poszczególnych grup pomagają stworzyć korzystne środowisko instytucji opiekuńczych.

Słowa kluczowe: instytucje opiekuńcze, etyka opieki, formalna opieka nad osobami starszymi, Czechy, komodyfikacja 